\title{
The response of date palm to calcareous soil fertilisation
}

\author{
H. A. Kassem \\ Plant Production Dept., College of Food and Agriculture Science, King Saud University, Saudi Arabia. \\ hkassem39@yahoo.com
}

\begin{abstract}
An experiment was conducted during two successive seasons, 2008/2009 and 2009/2010, on the Zaghloul date palm cultivar grown in calcareous loamy sand and irrigated with drainage water. The purpose of the experiment was to investigate the effects of $1,000 \mathrm{~g}$ total $\mathrm{N}$ per palm applied as either ammonium sulphate, ammonium nitrate or urea and two levels of potassium $\left(\mathrm{K}_{2} \mathrm{O}\right)$ and elemental sulphur $(\mathrm{S})$ on the nutritional status, productivity and fruit quality of the cultivar. The results of the study showed that the ammonium sulphate form (N1) increased the fruit yield, weight, length and colour compared to the ammonium nitrate (N2) or the urea form (N3). Fruit TSS, sugars, anthocyanin and dry matter content increased, whereas fruit acidity and tannins decreased under N1 fertilisation. Furthermore, the potassium and sulphur fertilisation enhanced the physico-chemical characteristics of the fruit. The $\mathrm{N} 1$ application increased the leaf $\mathrm{N}, \mathrm{K}, \mathrm{Ca}, \mathrm{Fe}$ and $\mathrm{Zn}$ contents, as did the potassium and sulphur application. The $\mathrm{N} 1$ application increased the fruit $\mathrm{N}, \mathrm{P}, \mathrm{K}, \mathrm{Fe}$ and $\mathrm{Zn}$ contents, whereas the fruit $\mathrm{Cd}, \mathrm{Pb}$ and $\mathrm{NO}_{3}$ were highest with $\mathrm{N} 2$. The potassium and sulphur applications increased the fruit $\mathrm{N}, \mathrm{Fe}, \mathrm{Mn}, \mathrm{Cd}, \mathrm{Pb}$ and $\mathrm{NO}_{3}$ contents.

Keywords: Fertilisation; Calcareous Soil; Drainage Water; Date Palm.
\end{abstract}




\section{Introduction}

Date palm (Phoenix dactylifera) is the most common fruit tree grown in semiarid and arid- regions of the Middle East and North Africa. In Egypt, many farmers rely on date palm cultivation. According to FAO (2010), Egypt is considered the leading country among the top ten date producers $(1,130,000$ tonnes). Date palm fruits are one of the most important export fruit crops in Egypt, where they are harvested and marketed at three stages of their development. The three stages are khalal (bisr), rutab and tamar. Dates in the khalal stage appear first in the harvesting season and therefore find a ready market. The best date varieties suitable for marketing at the khalal stage are Zaghloul dates, which are the most economically important soft cultivars grown in Egypt. Generally, they are grown and are highly productive under stringent environmental conditions that may be not suitable for many other species of fruit trees. The palms investigated in the present study were grown in loamy calcareous soil and irrigated with drainage water. These conditions strongly influence the amount of nutrient uptake. Therefore, the adaptation of a proper fertilisation program, including adequate rates, appropriate sources and efficient application methods and timing are important strategies for obtaining better yield and fruit quality (Fageria and Baligar, 2005).

Nitrogen is known to be one of the most important elements for plant nutrition and development because it plays an important role as a constituent of all proteins, nucleic acids and enzymes (Nijjar, 1985). The forms and levels of nitrogen, the cultivars considered and the physico-chemical properties of the soil are all related to the use of nitrogen by plants ( $\mathrm{Li}$ et al., 2007). The form of nitrogen applied can play a significant role in plant growth and productivity (Sady et al., 2008). Ammonium $\left(\mathrm{NH}_{4}^{+}\right)$, nitrate $\left(\mathrm{NO}_{3}^{-}\right)$and urea are the forms of nitrogen generally applied. Different nitrogen sources may be preferred for use with different plant species (Marschner, 1995). The responses of a large number of fruit trees to the application of different nitrogen forms have been reported previously (Saleh et al., 2000).

Potassium is also an important nutrient for date palm growth and productivity (Al-Kharusi et al., 2009). Potassium is necessary for basic physiological functions, such as the formation of sugars and starch, the synthesis of proteins, cell division and growth, fruit formation and could improve fruit size, flavour and colour (Abbas and Fares, 2008). Potassium has been shown to promote plant disease reduction, and potassium stress can increase the degree of crop damage by bacterial and fungal diseases (Holzmueller et al., 2007). Furthermore, the last few years have seen increasing concern regarding the use of sulphur applications to reduce alkalinity in calcareous soil (Abbey et al., 2002), and sulphur has become one of the most strongly limiting nutrients in agricultural production (Eriksen et al., 2004).

In the present market economy, product quality has become increasingly important. Therefore, the objectives of the present study were to investigate the effects of different forms of nitrogen and potassium $\left(\mathrm{K}_{2} \mathrm{O}\right)$ and sulphur fertilisation $(\mathrm{S})$ rates on the yield, leaf and fruit mineral content, fruit marketing characteristics and food quality of Zaghloul dates grown in calcareous soil irrigated with drainage water.

\section{Material and methods}

\subsection{Plant materials, treatments and experimental design}

The present study was conducted during the 2008/2009 and 2009/2010 seasons on 22 year-old Zaghloul date 
palm trees grown in calcareous loamy, sandy soil inat a private orchard located in the Mariut region, near Alexandria, Egypt.

The palms were planted 10 metres apart and irrigated with drainage water. Analyses of the soil and irrigation water are presented in Table 1. In December 2008 and December 2009, cattle manure $(\sim 1.5 \%$ $\mathrm{N})$ and calcium superphosphate $\left(15.5 \% \mathrm{P}_{2} \mathrm{O}_{5}\right)$ were applied at the rates of 25-30 and $1.5 \mathrm{~kg} /$ tree, respectively. All the routine agro-technical operations were performed according to the traditional schedule for date palm culture. The leaf/bunch ratio was adjusted in both years by the end of the blooming season to a value of 10:1 for all experimental palms.

One kilogram of total nitrogen per palm was applied as ammonium sulphate $(21.5 \% \mathrm{~N})(\mathrm{N} 1)$, ammonium nitrate $(33.5 \% \mathrm{~N})(\mathrm{N} 2)$ or urea $(46 \% \mathrm{~N})(\mathrm{N} 3)$. Two potassium $\left(\mathrm{K}_{2} \mathrm{O}\right)$ levels $(\mathrm{K} 0=0.0$ and $\mathrm{K} 1=750 \mathrm{~g}$ $\mathrm{K}_{2} \mathrm{O} /$ palm) as potassium sulphate $\left(48 \% \mathrm{~K}_{2} \mathrm{O}\right)$ and two elemental sulphur levels $(\mathrm{S} 0=0.0$ and $\mathrm{S} 1=500 \mathrm{~g}$ / palm). These nutrients were applied alone or in combinations to study their influence on leaf mineral content, palm yield and fruit quality.

In both experimental years, the nitrogen fertiliser was divided into four equal doses and added in March, April, May and July. The potassium fertiliser was divided into three equal doses and added in March, May and August. The elemental sulphur was applied as a single dose in December with the manure fertiliser. Twelve fertilisation treatments representing all possible combinations of the three forms of nitrogen fertiliser, two levels of $\mathrm{K}_{2} \mathrm{O}$ and two levels of $\mathrm{S}$ fertiliser were used $(3 \times 2 \times 2=12$ treatments $)$. Each treatment was broadcast on the soil surface $(\sim$ 1.5 metre from the palm trunk). The palms were irrigated immediately after addition of the fertiliser. The experiment was conducted as a split-split plot study in a randomised complete design with three replicates $(1$ replicate $=$ one palm $)$ for each treatment $(3$ repli- cates $\times 3 \mathrm{~N}$ forms $\times 2 \mathrm{~K}_{2} \mathrm{O}$ levels $\times 2 \mathrm{~S}$ levels). The study used 36 palms with uniform characteristics. The soil moisture content was kept at an appropriate field capacity for sandy soil (50-75\%).

\subsection{Yield}

In both study years, the palms were harvested in mid-October when fruits reached the khalal stage (fully mature, crunchy and red in colour). The average fruit yield/tree and bunch weight were recorded in kilograms. Additionally, fruit samples were randomly taken from four different bunches to determine the values of the physico-chemical characteristics chosen to represent fruit quality.

\subsection{Fruit physico-chemical characteristics}

A fruit sample of 30 mature dates was collected for each replicate. The fruit weight $(\mathrm{g})$, length $(\mathrm{cm})$, width (cm) and shape (length/width) were determined. The fruit colour was measured with the following colour intensity scale: $(1)=100 \%$ green, $(2)=25 \%$ red, ( $(3)=$ $50 \%$ red, (4) $=75 \%$ red and $(5)=100 \%$ red.

A sample of 40 mature dates for each replicate was used to determine the chemical characteristics of the fruit. The fruits were peeled at evenly spaced locations in their equatorial region and were cut into small pieces with a clean knife. The anthocyanin content in $1 \mathrm{~g}$ fruit peel tissue was determined according to Fuleki and Francis (1968). Five grams were taken from the fresh whole fruit (peel + pulp) to extract the reducing and non-reducing sugars with water at $85^{\circ} \mathrm{C}$ and the 3,5- dinitrosalicylic acid to extract the sugars (Barbin, 2006). The percentage of non-reducing sugars was determined by hydrolysis with hydrochloric acid to produce reducing sugars. The percentage of reducing sugars and the amount of total sugars was determined according to AOAC (1995). The non-re- 
ducing sugar content was determined by calculating the difference between the total sugar content and the reducing sugar content. Another $5 \mathrm{~g}$ sample was taken to determine the soluble tannin content $(\mathrm{g} / 100 \mathrm{~g}$ fresh weight) according to Abou Sayed et al. (1997). The percentage of total soluble solids (TSS) in the fruit juice was determined using a hand refractometer. The acidity (as malic acid) was determined according to AOAC (1995).

\subsection{Leaf and fruit dry matter and mineral content}

Another sample of 40 fruits was used to determine the dry matter and mineral content. The fruits were cut into pieces with a clean knife. A quantity of the fresh fruit was weighed (fresh weight) and air-dried to a constant weight $(\mathrm{g})$ in an oven at $70^{\circ} \mathrm{C}$. The dried fruit was then weighed (dry weight), and the fruit dry matter content was calculated as follows:

Fruit dry matter $(\%)=$ [average dry weight/average fresh weight] $\times 100$.

In mid-October of both growing seasons, three consecutive leaves (located just below the fruiting zone and approximately two years old) were chosen at random from each replicate (Reuther, 1948). The leaf samples were washed with tap water, rinsed twice in distilled water and air dried in an oven at $70^{\circ} \mathrm{C}$. The dried leaves and fruits were ground and digested with $\mathrm{H}_{2} \mathrm{O}_{2}$ and $\mathrm{H}_{2} \mathrm{SO}_{4}$ according to Evanhuis and De Waard (1980). Suitable aliquots were taken for the determination of the mineral content. Nitrogen was determined by the Kjeldahl method (AOAC, 1995). Phosphorus was determined by the ascorbic acid method according to Murphy and Riley (1962). Potassium and sodium were determined with a flame photometer. The $\mathrm{Ca}, \mathrm{Mg}, \mathrm{Fe}, \mathrm{Zn}, \mathrm{Mn}, \mathrm{Cu}, \mathrm{Pb}$ and $\mathrm{Cd}$ contents were measured using a Model 305 atomic absorption spectrophotometer (Perkin-Elmer Corp., Norwalk, CT 06586). The concentrations of N, P, K, $\mathrm{Ca}, \mathrm{Na}$ and $\mathrm{Mg}$ were expressed as percentages. The concentrations of $\mathrm{Fe}, \mathrm{Mn}, \mathrm{Zn}, \mathrm{Cu}, \mathrm{Pb}$ and $\mathrm{Cd}$ were expressed as parts per million (ppm) on a dry weight basis. The nitrate content of the fruit was determined spectrophotometrically at $540 \mathrm{~nm}$, then calculated as $\mathrm{mg} / \mathrm{kg}$ dry weight as described by Singh (1988).

\subsection{Statistical analysis}

The obtained results were evaluated using a splitsplit plot design with a three-way analysis of variance (ANOVA). In the randomised complete design, the $\mathrm{N}$ forms were randomised in the main plot, the potassium levels were assigned to the subplots and the sulphur rate was assigned to the subplots. The main effects of the nitrogen form, potassium and sulphur level were compared using a least significant difference (L.S.D.) test at the 0.05 significance level. Calculations were performed with Statistica ${ }^{\mathrm{TM}}$ for Windows software version 6.1 (Statsoft Inc., 2001, Tulsa, Oklahoma, USA). 
Table 1. Analysis of the experimental orchard soil and irrigation water.

\begin{tabular}{|c|c|c|c|c|}
\hline \multirow{2}{*}{ Properties } & \multirow{2}{*}{ Units } & \multicolumn{2}{|c|}{ Orchard Soil } & \multirow{2}{*}{ Irrigation water } \\
\hline & & $50-100 \mathrm{~cm}$ & $0-50 \mathrm{~cm}$ & \\
\hline $\mathrm{EC}$ & $\mathrm{dS} \mathrm{m}-1$ & 3.3 & 4.1 & 3.8 \\
\hline $\mathrm{pH}$ & & 8.2 & 7.9 & 7.2 \\
\hline $\mathrm{HCO}_{3}^{-}$ & meq L-1 & 10 & 12 & 10.8 \\
\hline $\mathrm{Ca}++$ & meq L-1 & 21.3 & 24.7 & 14 \\
\hline $\mathrm{Mg}++$ & meq L-1 & 8.6 & 10.5 & 7.6 \\
\hline $\mathrm{K}+$ & meq L-1 & 2.4 & 1.3 & 1.1 \\
\hline $\mathrm{Na}+$ & meq L-1 & 12.6 & 18.2 & 17.5 \\
\hline $\mathrm{Cl}_{2}^{-}$ & meq L-1 & 21 & 17.3 & 17.6 \\
\hline $\mathrm{Fe}$ & ppm & 20.9 & 16.3 & 0.75 \\
\hline $\mathrm{Mn}$ & pmn & 32.8 & 15.5 & 0.21 \\
\hline $\mathrm{Zn}$ & ppm & 11.6 & 6.7 & 0.62 \\
\hline $\mathrm{Cu}$ & ppm & 14.8 & 11.8 & 0.60 \\
\hline Organic matter & $(\%)$ & 1.3 & 0.4 & - \\
\hline $\mathrm{CaCO}_{3}$ & $(\%)$ & 32.1 & 35.4 & - \\
\hline
\end{tabular}

\section{Results}

\subsection{Yield}

For all the potassium and sulphur applications, the results showed that the yield components were higher with the applications of N1 and N2 than with N3. Furthermore, N1 resulted in a higher yield than N2. In addition, potassium (regardless of the $\mathrm{N}$ form and the $\mathrm{S}$ application) and sulphur (regardless of the $\mathrm{N}$ form and the $\mathrm{K}_{2} \mathrm{O}$ application) fertilisation significantly increased the fruit yield in both seasons (Table 2).

\subsection{Fruit physico-chemical characteristics}

The data from both seasons also indicated that regardless of the $\mathrm{K}_{2} \mathrm{O}$ and $\mathrm{S}$ applications, the fruit weight was higher with the application of N1 than with N3. However, the fruit weight was significantly higher in the first season with the application of $\mathrm{N} 2$ than with $\mathrm{N} 1$ and N3. Furthermore, the fruit length was greater in both seasons with the application of N1 than with $\mathrm{N} 2$ and N3. The fruit width was greater in the second season with the application of N1 and N2 than with N3. However, the different forms of nitrogen did not produce significant differences in fruit shape (Table 2 ). The fruit colour value was significantly greater with the application of $\mathrm{N} 1$ than with $\mathrm{N} 3$ in both seasons. N1 and N2 did not produce a significant difference in fruit colour. Potassium and sulphur fertilisation significantly increased the fruit weight, length, width and colour, whereas the fruit shape was not affected (Table 2). 
Table 2. Main effects of nitrogen forms, potassium and sulphur on the fruit yield and the physical characteristics of the Zaghloul date in the 2008/2009 and 2009/2010 seasons.

\begin{tabular}{|c|c|c|c|c|c|c|c|}
\hline \multirow{3}{*}{ Treat. } & \multirow{2}{*}{\multicolumn{2}{|c|}{ Yield }} & \multicolumn{4}{|c|}{ Fruit } & \multirow{3}{*}{ Red color } \\
\hline & & & \multirow{2}{*}{$\begin{array}{c}\text { Weight } \\
(\mathrm{g})\end{array}$} & \multirow{2}{*}{$\begin{array}{l}\text { Length } \\
(\mathrm{cm})\end{array}$} & \multirow{2}{*}{$\begin{array}{l}\text { Width } \\
(\mathrm{cm})\end{array}$} & \multirow{2}{*}{ Shape } & \\
\hline & $\mathrm{Kg} /$ palm & $\mathrm{Kg} /$ bunch & & & & & \\
\hline \multicolumn{8}{|c|}{ 2008-2009 } \\
\hline $\mathrm{N}_{1}$ & $218^{\mathrm{a}}$ & $22^{\mathrm{a}}$ & $25.6^{\mathrm{b}}$ & $6.6^{\mathrm{a}}$ & $2.8^{\mathrm{a}}$ & $2.4^{\mathrm{a}}$ & $4.8^{\mathrm{a}}$ \\
\hline $\mathrm{N}_{2}$ & $200^{\mathrm{b}}$ & $20^{\mathrm{b}}$ & $26.7^{\mathrm{a}}$ & $6.1^{\mathrm{b}}$ & $2.6^{\mathrm{a}}$ & $2.4^{\mathrm{a}}$ & $4.5^{\mathrm{ab}}$ \\
\hline $\mathrm{N}_{3}$ & $180^{\mathrm{c}}$ & $18^{c}$ & $24.4^{c}$ & $5.6^{\mathrm{c}}$ & $2.4^{\mathrm{a}}$ & $2.3^{\mathrm{a}}$ & $4.3^{\mathrm{b}}$ \\
\hline K0 & $188^{\mathrm{b}}$ & $18^{\mathrm{b}}$ & $24.5^{\mathrm{b}}$ & $5.6^{\mathrm{b}}$ & $2.2^{\mathrm{b}}$ & $2.5^{\mathrm{a}}$ & $4.2^{\mathrm{b}}$ \\
\hline $\mathrm{K} 1$ & $211^{\mathrm{a}}$ & $22^{\mathrm{a}}$ & $26.7^{\mathrm{a}}$ & $6.6^{\mathrm{a}}$ & $3.0^{\mathrm{a}}$ & $2.2^{\mathrm{b}}$ & $4.9^{\mathrm{a}}$ \\
\hline S0 & $192^{\mathrm{b}}$ & $17^{\mathrm{b}}$ & $25.2^{\mathrm{b}}$ & $5.9^{\mathrm{b}}$ & $2.4^{\mathrm{b}}$ & $2.5^{\mathrm{a}}$ & $4.5^{\mathrm{b}}$ \\
\hline S1 & $207^{\mathrm{a}}$ & $23^{\mathrm{a}}$ & $26.0^{\mathrm{a}}$ & $6.4^{\mathrm{a}}$ & $2.8^{\mathrm{a}}$ & $2.3^{\mathrm{a}}$ & $4.6^{\mathrm{a}}$ \\
\hline \multicolumn{8}{|c|}{$2009-2010$} \\
\hline N1 & $191^{\mathrm{a}}$ & $19^{\mathrm{a}}$ & $28.8^{\mathrm{a}}$ & $6.9^{\mathrm{a}}$ & $3.0^{\mathrm{a}}$ & $2.3^{\mathrm{a}}$ & $4.9^{\mathrm{a}}$ \\
\hline $\mathrm{N} 2$ & $179^{\mathrm{a}}$ & $18^{\mathrm{ab}}$ & $26.1^{\mathrm{b}}$ & $6.6^{\mathrm{b}}$ & $2.9^{\mathrm{a}}$ & $2.3^{\mathrm{a}}$ & $4.7^{\mathrm{ab}}$ \\
\hline N3 & $166^{\mathrm{b}}$ & $17^{\mathrm{b}}$ & $25.3^{\mathrm{b}}$ & $5.7^{\mathrm{c}}$ & $2.5^{\mathrm{b}}$ & $2.3^{\mathrm{a}}$ & $4.2^{\mathrm{b}}$ \\
\hline K0 & $160^{\mathrm{b}}$ & $15^{\mathrm{b}}$ & $23.3^{\mathrm{b}}$ & $5.8^{\mathrm{b}}$ & $2.5^{\mathrm{b}}$ & $2.3^{\mathrm{a}}$ & $4.4^{\mathrm{b}}$ \\
\hline $\mathrm{K} 1$ & $197^{\mathrm{a}}$ & $21^{\mathrm{a}}$ & $30.2^{\mathrm{a}}$ & $7.0^{\mathrm{a}}$ & $3.1^{\mathrm{a}}$ & $2.3^{\mathrm{a}}$ & $4.8^{\mathrm{a}}$ \\
\hline S0 & $170^{\mathrm{b}}$ & $16^{\mathrm{b}}$ & $26.5^{\mathrm{b}}$ & $6.0^{\mathrm{b}}$ & $2.6^{\mathrm{b}}$ & $2.2^{\mathrm{a}}$ & $4.3^{\mathrm{b}}$ \\
\hline S1 & $187^{\mathrm{a}}$ & $20^{\mathrm{a}}$ & $27.0^{\mathrm{a}}$ & $6.8^{\mathrm{a}}$ & $3.0^{\mathrm{a}}$ & $2.4^{\mathrm{a}}$ & $4.9^{\mathrm{a}}$ \\
\hline
\end{tabular}

Values within a column with same letter are not significantly different $(p<0.05)$.

The results of the study indicated that regardless of the $\mathrm{K}_{2} \mathrm{O}$ and $\mathrm{S}$ rates, the fruit acidity was lower with the applications of N1 and N2 than with N3 in the first season (Table 3). The fruit TSS content was significantly greater with $\mathrm{N} 1$ than with $\mathrm{N} 2$ in the second season and significantly greater with $\mathrm{N} 1$ than with N3 in both seasons. The content of non-reducing sugars in the fruit was greater with N1 and N2 than with N3 in the second season. The content of reducing sugars in the fruit and the total sugar content was greater with N1 and N2 than with N3 in both seasons. The fruit tannin values were lower with N1 than with N3 in both seasons. However, the lowest value of tannins was observed with N2 in the second season. The anthocyanin content was greater with $\mathrm{N} 1$ and $\mathrm{N} 2$ than with N3 in both seasons. The dry matter content of the fruit was greater with N1 than with N2 and N3 (Table 3).

Potassium fertilisation produced a significant increase in fruit acidity, whereas fruit acidity was not affected by the sulphur application. The potassium and sulphur applications increased the fruit TSS, anthocyanin, dry matter, reducing sugar and total sugar content significantly. The non-reducing sugar 
content was increased by potassium fertilisation, whereas it was not affected by sulphur application. An obvious decrease in fruit tannin was observed with potassium fertilisation in both seasons, whereas sulphur application lowered the fruit tannin content only in the first season.

Table 3. Main effects of nitrogen forms, potassium and sulphur on the fruit chemical characteristics of the Zaghloul date in the 2008/2009 and 2009/2010 seasons.

\begin{tabular}{|c|c|c|c|c|c|c|c|c|}
\hline \multirow{2}{*}{ Treatments } & \multirow{2}{*}{$\begin{array}{c}\text { Acidity } \\
(\%)\end{array}$} & \multirow{2}{*}{$\begin{array}{r}\text { TSS } \\
(\%)\end{array}$} & \multicolumn{3}{|c|}{ Sugar (\%) } & \multirow{2}{*}{$\begin{array}{c}\text { Tannins } \\
(\%) \\
\end{array}$} & \multirow{2}{*}{$\begin{array}{l}\text { Anthocyanin } \\
\left(\mathrm{mg} 100 \mathrm{~g}^{-1}\right)\end{array}$} & \multirow{2}{*}{$\begin{array}{c}\text { Dry matter } \\
(\%)\end{array}$} \\
\hline & & & Non-reducing & Red & ing Total & & & \\
\hline \multicolumn{9}{|l|}{$2008 / 2009$} \\
\hline $\mathrm{N}_{1}$ & $0.33^{\mathrm{b}}$ & $27.5^{\mathrm{a}}$ & $5.5^{\mathrm{a}}$ & $27.2^{\mathrm{a}}$ & $32.7^{\mathrm{a}}$ & $0.48^{\mathrm{b}}$ & $22.3^{a}$ & $32.8^{\mathrm{a}}$ \\
\hline $\mathrm{N}_{2}$ & $0.35^{\mathrm{b}}$ & $26.4^{\mathrm{ab}}$ & $5.6^{\mathrm{a}}$ & $26.5^{\mathrm{a}}$ & $32.1^{\mathrm{a}}$ & $0.50^{\mathrm{ab}}$ & $21.8^{\mathrm{a}}$ & $29.7^{\mathrm{b}}$ \\
\hline $\mathrm{N}_{3}$ & $0.41^{\mathrm{a}}$ & $25.3^{\mathrm{b}}$ & $5.0^{\mathrm{a}}$ & $24.4^{\mathrm{b}}$ & $29.4^{b}$ & $0.60^{\mathrm{a}}$ & $17.5^{\mathrm{b}}$ & $27.8^{c}$ \\
\hline K0 & $0.32^{\mathrm{b}}$ & $25.8^{\mathrm{b}}$ & $5.0^{\mathrm{b}}$ & $25.1^{\mathrm{b}}$ & $30.1^{\mathrm{b}}$ & $0.68^{\mathrm{a}}$ & $19.1^{\mathrm{b}}$ & $29.2^{\mathrm{b}}$ \\
\hline $\mathrm{K} 1$ & $0.40^{\mathrm{a}}$ & $27.0^{\mathrm{a}}$ & $5.7^{\mathrm{a}}$ & $27.0^{\mathrm{a}}$ & $32.7^{\mathrm{a}}$ & $0.37^{\mathrm{b}}$ & $22.0^{\mathrm{a}}$ & $31.0^{\mathrm{a}}$ \\
\hline S0 & $0.35^{\mathrm{a}}$ & $25.5^{\mathrm{b}}$ & $5.0^{\mathrm{a}}$ & $25.5^{\mathrm{b}}$ & $30.5^{b}$ & $0.59^{\mathrm{a}}$ & $19.1^{\mathrm{b}}$ & $27.8^{\mathrm{b}}$ \\
\hline $\mathrm{S} 1$ & $0.37^{\mathrm{a}}$ & $27.3^{\mathrm{a}}$ & $5.7^{\mathrm{a}}$ & $26.5^{\mathrm{a}}$ & $32.2^{\mathrm{a}}$ & $0.47^{\mathrm{b}}$ & $22.0^{\mathrm{a}}$ & $32.4^{\mathrm{a}}$ \\
\hline \multicolumn{9}{|l|}{$2009 / 2010$} \\
\hline $\mathrm{N}_{1}$ & $0.36^{\mathrm{a}}$ & $28.2^{\mathrm{a}}$ & $5.9^{\mathrm{a}}$ & $26.4^{\mathrm{a}}$ & $32.3^{\mathrm{a}}$ & $0.29^{b}$ & $22.9^{a}$ & $35.6^{\mathrm{a}}$ \\
\hline $\mathrm{N}_{2}$ & $0.33^{\mathrm{a}}$ & $27.2^{\mathrm{b}}$ & $5.8^{\mathrm{a}}$ & $25.6^{\mathrm{a}}$ & $31.4^{\mathrm{a}}$ & $0.24^{\mathrm{c}}$ & $20.4^{b}$ & $32.6^{\mathrm{b}}$ \\
\hline $\mathrm{N}_{3}$ & $0.34^{\mathrm{a}}$ & $25.9^{c}$ & $4.0^{\mathrm{b}}$ & $22.5^{\mathrm{b}}$ & $26.5^{\mathrm{b}}$ & $0.46^{\mathrm{a}}$ & $16.5^{\mathrm{c}}$ & $31.7^{\mathrm{b}}$ \\
\hline K0 & $0.32^{\mathrm{b}}$ & $24.9^{\mathrm{b}}$ & $4.6^{\mathrm{b}}$ & $22.6^{\mathrm{b}}$ & $27.2^{b}$ & $0.43^{\mathrm{a}}$ & $18.3^{\mathrm{b}}$ & $31.7^{\mathrm{b}}$ \\
\hline $\mathrm{K} 1$ & $0.37^{\mathrm{a}}$ & $29.3^{\mathrm{a}}$ & $5.9^{\mathrm{a}}$ & $27.1^{\mathrm{a}}$ & $33.0^{\mathrm{a}}$ & $0.23^{\mathrm{b}}$ & $21.6^{\mathrm{a}}$ & $34.9^{\mathrm{a}}$ \\
\hline S0 & $0.34^{\mathrm{a}}$ & $26.5^{\mathrm{b}}$ & $4.6^{\mathrm{a}}$ & $24.1^{\mathrm{b}}$ & $28.7^{\mathrm{b}}$ & $0.31^{\mathrm{a}}$ & $18.3^{b}$ & $31.3^{\mathrm{b}}$ \\
\hline S1 & $0.35^{\mathrm{a}}$ & $27.7^{\mathrm{a}}$ & $5.9^{\mathrm{a}}$ & $25.6^{\mathrm{a}}$ & $31.6^{\mathrm{a}}$ & $0.35^{\mathrm{a}}$ & $21.6^{\mathrm{a}}$ & $35.5^{\mathrm{a}}$ \\
\hline
\end{tabular}

Values within a column with same letter are not significantly different $(p<0.05)$.

\subsection{Leaf and fruit mineral content}

Regardless of the $\mathrm{K}_{2} \mathrm{O}$ and $\mathrm{S}$ application, the results showed that leaf $\mathrm{N}$ was greater with the application of $\mathrm{N} 1$ and $\mathrm{N} 2$ than with $\mathrm{N} 3$. The leaf $\mathrm{P}, \mathrm{K}, \mathrm{Ca}, \mathrm{Fe}$ and Zn contents were greater with N1 than with N3. However, the leaf $\mathrm{Mg}$ and $\mathrm{Mn}$ contents were greater with $\mathrm{N} 2$ than with $\mathrm{N} 1$ and N3. The leaf Na content was not affected by the $\mathrm{N}$ form (Tables 4 and 5 ).
The study also showed that the leaf N, P, K, Fe, $\mathrm{Zn}$ and $\mathrm{Mn}$ contents were increased significantly by the potassium and sulphur fertilisation. However, the $\mathrm{Ca}$ and $\mathrm{Mg}$ contents decreased with the potassium application, whereas $\mathrm{Ca}$ was not affected by the application of sulphur fertiliser. The leaf $\mathrm{Na}$ and $\mathrm{Cu}$ contents decreased with the sulphur application and were not affected by the potassium fertiliser. 
Table 4. Main effects of nitrogen forms, potassium and sulphur on the leaf and fruit macronutrient contents (\%) of the Zaghloul date in the 2008/2009 and 2009/2010 seasons.

\begin{tabular}{|c|c|c|c|c|c|c|c|c|c|c|c|c|}
\hline \multirow{2}{*}{ Treatments } & \multicolumn{2}{|c|}{$\mathrm{N}$} & \multicolumn{2}{|c|}{$P$} & \multicolumn{2}{|c|}{ K } & \multicolumn{2}{|c|}{$\mathrm{Ca}$} & \multicolumn{2}{|c|}{$\mathrm{Mg}$} & \multicolumn{2}{|c|}{$\mathrm{Na}$} \\
\hline & Leaf & Fruit & Leaf & Fruit & Leaf & Fruit & Leaf & Fruit & Leaf & Fruit & Leaf & Fruit \\
\hline \multicolumn{13}{|l|}{$2008 / 2009$} \\
\hline N1 & $2.45^{\mathrm{a}}$ & $1.64^{\mathrm{a}}$ & $0.36^{\mathrm{a}}$ & $0.21^{\mathrm{a}}$ & $1.96^{\mathrm{a}}$ & $0.98^{\mathrm{a}}$ & $1.48^{\mathrm{a}}$ & $0.76^{\mathrm{a}}$ & $0.40^{\mathrm{b}}$ & $0.31^{\mathrm{b}}$ & $0.38^{\mathrm{a}}$ & $0.18^{\mathrm{a}}$ \\
\hline $\mathrm{N} 2$ & $2.38^{\mathrm{a}}$ & $1.38^{\mathrm{b}}$ & $0.27^{b}$ & $0.17^{\mathrm{a}}$ & $1.82^{\mathrm{ab}}$ & $0.94^{\mathrm{a}}$ & $1.32^{\mathrm{b}}$ & $0.82^{\mathrm{a}}$ & $0.57^{\mathrm{a}}$ & $0.45^{\mathrm{a}}$ & $0.33^{\mathrm{a}}$ & $0.21^{\mathrm{a}}$ \\
\hline N3 & $2.24^{\mathrm{b}}$ & $1.25^{\mathrm{b}}$ & $0.29^{\mathrm{b}}$ & $0.19^{\mathrm{a}}$ & $1.70^{\mathrm{b}}$ & $0.81^{\mathrm{b}}$ & $1.28^{\mathrm{b}}$ & $0.78^{\mathrm{a}}$ & $0.42^{\mathrm{b}}$ & $0.35^{\mathrm{b}}$ & $0.38^{\mathrm{a}}$ & $0.25^{\mathrm{a}}$ \\
\hline K0 & $2.28^{\mathrm{b}}$ & $1.33^{\mathrm{b}}$ & $0.25^{\mathrm{b}}$ & $0.18^{\mathrm{a}}$ & $1.70^{\mathrm{b}}$ & $0.81^{\mathrm{b}}$ & $1.42^{\mathrm{a}}$ & $0.87^{\mathrm{a}}$ & $0.56^{\mathrm{a}}$ & $0.43^{\mathrm{a}}$ & $0.38^{\mathrm{a}}$ & $0.19^{\mathrm{a}}$ \\
\hline K1 & $2.43^{\mathrm{a}}$ & $1.52^{\mathrm{a}}$ & $0.30^{\mathrm{a}}$ & $0.20^{\mathrm{a}}$ & $1.95^{\mathrm{a}}$ & $1.01^{\mathrm{a}}$ & $1.30^{\mathrm{b}}$ & $0.70^{\mathrm{b}}$ & $0.37^{\mathrm{b}}$ & $0.32^{\mathrm{b}}$ & $0.35^{\mathrm{a}}$ & $0.24^{\mathrm{a}}$ \\
\hline S0 & $2.23^{\mathrm{b}}$ & $1.27^{\mathrm{b}}$ & $0.28^{\mathrm{b}}$ & $0.17^{\mathrm{a}}$ & $1.73^{\mathrm{b}}$ & $0.84^{\mathrm{a}}$ & $1.38^{\mathrm{a}}$ & $0.87^{\mathrm{a}}$ & $0.40^{\mathrm{b}}$ & $0.33^{\mathrm{a}}$ & $0.42^{\mathrm{a}}$ & $0.24^{\mathrm{a}}$ \\
\hline S1 & $2.48^{\mathrm{a}}$ & $1.58^{\mathrm{a}}$ & $0.33^{\mathrm{a}}$ & $0.21^{\mathrm{a}}$ & $1.92^{\mathrm{a}}$ & $0.98^{\mathrm{a}}$ & $1.34^{\mathrm{a}}$ & $0.70^{\mathrm{a}}$ & $0.53^{\mathrm{a}}$ & $0.42^{\mathrm{a}}$ & $0.31^{\mathrm{b}}$ & $0.19^{\mathrm{a}}$ \\
\hline \multicolumn{13}{|l|}{$2009 / 2010$} \\
\hline N1 & $2.56^{\mathrm{a}}$ & $1.51^{\mathrm{a}}$ & $0.37^{\mathrm{a}}$ & $0.24^{\mathrm{a}}$ & $1.98^{\mathrm{a}}$ & $0.90^{\mathrm{a}}$ & $1.55^{\mathrm{a}}$ & $0.83^{\mathrm{ab}}$ & $0.48^{\mathrm{b}}$ & $0.40^{\mathrm{b}}$ & $0.38^{\mathrm{a}}$ & $0.22^{\mathrm{a}}$ \\
\hline N2 & $2.58^{\mathrm{a}}$ & $1.24^{\mathrm{b}}$ & $0.31^{\mathrm{b}}$ & $0.20^{\mathrm{ab}}$ & $1.74^{\mathrm{b}}$ & $0.93^{\mathrm{a}}$ & $1.53^{\mathrm{a}}$ & $0.93^{\mathrm{a}}$ & $0.62^{\mathrm{a}}$ & $0.55^{\mathrm{a}}$ & $0.32^{\mathrm{a}}$ & $0.19^{\mathrm{a}}$ \\
\hline N3 & $2.42^{\mathrm{b}}$ & $1.28^{\mathrm{b}}$ & $0.26^{\mathrm{c}}$ & $0.18^{\mathrm{b}}$ & $1.62^{\mathrm{b}}$ & $0.73^{\mathrm{b}}$ & $1.33^{\mathrm{b}}$ & $0.79^{\mathrm{b}}$ & $0.42^{\mathrm{b}}$ & $0.38^{\mathrm{b}}$ & $0.34^{\mathrm{a}}$ & $0.26^{\mathrm{a}}$ \\
\hline K0 & $2.40^{\mathrm{b}}$ & $1.21^{\mathrm{b}}$ & $0.29^{\mathrm{b}}$ & $0.20^{\mathrm{a}}$ & $1.62^{\mathrm{b}}$ & $0.68^{\mathrm{b}}$ & $1.70^{\mathrm{a}}$ & $0.94^{\mathrm{a}}$ & $0.58^{\mathrm{a}}$ & $0.54^{\mathrm{a}}$ & $0.39^{\mathrm{a}}$ & $0.25^{\mathrm{a}}$ \\
\hline K1 & $2.64^{\mathrm{a}}$ & $1.48^{\mathrm{a}}$ & $0.34^{\mathrm{a}}$ & $0.21^{\mathrm{a}}$ & $1.94^{\mathrm{a}}$ & $1.00^{\mathrm{a}}$ & $1.24^{\mathrm{b}}$ & $0.76^{\mathrm{b}}$ & $0.43^{\mathrm{b}}$ & $0.35^{\mathrm{b}}$ & $0.30^{\mathrm{a}}$ & $0.20^{\mathrm{a}}$ \\
\hline S0 & $2.40^{\mathrm{b}}$ & $1.22^{\mathrm{b}}$ & $0.26^{\mathrm{b}}$ & $0.19^{\mathrm{a}}$ & $1.69^{\mathrm{b}}$ & $0.68^{\mathrm{a}}$ & $1.55^{\mathrm{a}}$ & $0.89^{\mathrm{a}}$ & $0.42^{\mathrm{b}}$ & $0.33^{\mathrm{a}}$ & $0.47^{\mathrm{a}}$ & $0.25^{\mathrm{a}}$ \\
\hline S1 & $2.64^{\mathrm{a}}$ & $1.47^{\mathrm{a}}$ & $0.37^{\mathrm{a}}$ & $0.22^{\mathrm{a}}$ & $1.87^{\mathrm{a}}$ & $1.03^{\mathrm{a}}$ & $1.39^{\mathrm{a}}$ & $0.81^{\mathrm{a}}$ & $0.59^{\mathrm{b}}$ & $0.56^{\mathrm{a}}$ & $0.22^{\mathrm{b}}$ & $0.20^{\mathrm{a}}$ \\
\hline
\end{tabular}

Values within a column with same letter are not significantly different $(p<0.05)$.

The results of the study (Tables 4 and 5) showed that the fruit $\mathrm{N}, \mathrm{Fe}$ and $\mathrm{Zn}$ contents were greater with the $\mathrm{N} 1$ application than with $\mathrm{N} 2$ and N3. In the second season, the fruit $\mathrm{P}$ and $\mathrm{Ca}$ contents were higher with N1 and N2, respectively, than with N3. In addition, the fruit $\mathrm{K}$ content was significantly greater with $\mathrm{N} 1$ and $\mathrm{N} 2$ than with N3. In contrast, the fruit $\mathrm{Mg}, \mathrm{Mn}$, $\mathrm{Cd}$ and $\mathrm{NO}_{3}$ contents were less with $\mathrm{N} 1$ and $\mathrm{N} 3$ than with $\mathrm{N} 2$. The fruit $\mathrm{Pb}$ content was less with $\mathrm{N} 1$ than with N2 and N3. However, the nitrogen form had no influence on the fruit $\mathrm{Na}$ and $\mathrm{Cu}$ contents.
The results of the study indicated that the fruit N, $\mathrm{K}, \mathrm{Fe}, \mathrm{Mn}, \mathrm{Cd}, \mathrm{Pb}$ and $\mathrm{NO}_{3}$ contents increased and the $\mathrm{Ca}$ and $\mathrm{Mg}$ contents decreased with the application of potassium fertiliser, whereas the fruit $\mathrm{P}, \mathrm{Na}$, $\mathrm{Zn}$ and $\mathrm{Cu}$ contents were not affected. In addition, the application of elemental sulphur significantly increased the fruit $\mathrm{N}, \mathrm{Fe}, \mathrm{Zn}, \mathrm{Mn}, \mathrm{Cd}$ and $\mathrm{Pb}$ contents and decreased the $\mathrm{Cu}$ and $\mathrm{NO}_{3}$ contents. In contrast, the fruit $\mathrm{P}, \mathrm{K}, \mathrm{Ca}, \mathrm{Mg}$ and $\mathrm{Na}$ contents were not influenced by the sulphur application (Tables 4 and 5). 
Table 5. Main effects of nitrogen forms, potassium and sulphur on the micronutrient contents of the leaf and fruit and the heavy-metal and nitrate contents (ppm) of the fruit of the Zaghloul date in the 2008/2009 and 2009/2010 seasons.

\begin{tabular}{|c|c|c|c|c|c|c|c|c|c|c|c|}
\hline \multirow{2}{*}{ Treatments } & \multicolumn{2}{|c|}{$\mathrm{Fe}$} & \multirow{2}{*}{$\frac{\mathrm{Zn}}{\text { Leaf }}$} & \multicolumn{3}{|c|}{$\mathrm{Mn}$} & \multicolumn{2}{|c|}{$\mathrm{Cu}$} & \multirow{2}{*}{$\frac{\mathrm{Cd}}{\text { Fruit }}$} & \multirow{2}{*}{$\frac{\mathrm{Pb}}{\text { Fruit }}$} & \multirow{2}{*}{$\frac{\mathrm{NO}_{3}}{\text { Fruit }}$} \\
\hline & Leaf & Fruit & & Fruit & Leaf & Fruit & Leaf & Fruit & & & \\
\hline \multicolumn{12}{|l|}{$2008 / 2009$} \\
\hline N1 & $124^{\mathrm{a}}$ & $68^{\mathrm{a}}$ & $49^{a}$ & $40^{\mathrm{a}}$ & $42^{b}$ & $28^{\mathrm{b}}$ & $29^{b}$ & $18^{\mathrm{a}}$ & $0.012^{\mathrm{c}}$ & $0.98^{\mathrm{b}}$ & $57^{b}$ \\
\hline $\mathrm{N} 2$ & $113^{\mathrm{ab}}$ & $59^{\mathrm{b}}$ & $44^{\mathrm{b}}$ & $32^{\mathrm{b}}$ & $52^{\mathrm{a}}$ & $39^{\mathrm{a}}$ & $30^{\mathrm{b}}$ & $23^{\mathrm{a}}$ & $0.021^{\mathrm{a}}$ & $1.21^{\mathrm{a}}$ & $76^{\mathrm{a}}$ \\
\hline N3 & $106^{\mathrm{b}}$ & $51^{\mathrm{c}}$ & $36^{\mathrm{c}}$ & $30^{\mathrm{b}}$ & $44^{\mathrm{b}}$ & $31^{\mathrm{b}}$ & $37^{a}$ & $17^{\mathrm{a}}$ & $0.016^{\mathrm{b}}$ & $1.14^{\mathrm{a}}$ & $58^{\mathrm{b}}$ \\
\hline K0 & $101^{\mathrm{b}}$ & $53^{\mathrm{b}}$ & $36^{\mathrm{b}}$ & $32^{\mathrm{a}}$ & $42^{b}$ & $27^{b}$ & $26^{\mathrm{a}}$ & $17^{\mathrm{a}}$ & $0.012^{\mathrm{b}}$ & $1.02^{\mathrm{b}}$ & $52^{\mathrm{b}}$ \\
\hline K1 & $128^{\mathrm{a}}$ & $66^{a}$ & $50^{\mathrm{a}}$ & $36^{\mathrm{a}}$ & $50^{\mathrm{a}}$ & $38^{\mathrm{a}}$ & $38^{\mathrm{a}}$ & $22^{\mathrm{a}}$ & $0.021^{\mathrm{a}}$ & $1.20^{\mathrm{a}}$ & $76^{\mathrm{a}}$ \\
\hline So & $105^{\mathrm{b}}$ & $52^{\mathrm{b}}$ & $40^{\mathrm{b}}$ & $22^{\mathrm{b}}$ & $33^{b}$ & $27^{b}$ & $35^{\mathrm{a}}$ & $22^{\mathrm{a}}$ & $0.010^{\mathrm{b}}$ & $1.04^{\mathrm{b}}$ & $68^{a}$ \\
\hline S1 & $124^{\mathrm{a}}$ & $67^{\mathrm{a}}$ & $46^{\mathrm{a}}$ & $46^{\mathrm{a}}$ & $59^{\mathrm{a}}$ & $38^{\mathrm{a}}$ & $29^{\mathrm{b}}$ & $17^{\mathrm{b}}$ & $0.023^{\mathrm{a}}$ & $1.18^{\mathrm{a}}$ & $60^{\mathrm{b}}$ \\
\hline \multicolumn{12}{|l|}{$2009 / 2010$} \\
\hline N1 & $133^{\mathrm{a}}$ & $74^{a}$ & $44^{\mathrm{a}}$ & $32^{\mathrm{a}}$ & $50^{\mathrm{b}}$ & $32^{b}$ & $39^{a}$ & $23^{\mathrm{a}}$ & $0.018^{b}$ & $1.02^{\mathrm{b}}$ & $61^{\mathrm{b}}$ \\
\hline $\mathrm{N} 2$ & $128^{\mathrm{a}}$ & $62^{\mathrm{b}}$ & $43^{\mathrm{a}}$ & $26^{\mathrm{b}}$ & $66^{\mathrm{a}}$ & $41^{\mathrm{a}}$ & $32^{\mathrm{b}}$ & $19^{\mathrm{a}}$ & $0.028^{\mathrm{a}}$ & $1.32^{\mathrm{a}}$ & $81^{\mathrm{a}}$ \\
\hline N3 & $111^{\mathrm{b}}$ & $58^{\mathrm{b}}$ & $30^{\mathrm{b}}$ & $27^{\mathrm{b}}$ & $53^{\mathrm{b}}$ & $28^{\mathrm{b}}$ & $34^{\mathrm{b}}$ & $23^{\mathrm{a}}$ & $0.019^{b}$ & $1.21^{\mathrm{a}}$ & $60^{\mathrm{b}}$ \\
\hline K0 & $116^{\mathrm{b}}$ & $56^{\mathrm{b}}$ & $34^{b}$ & 25 & $51^{\mathrm{b}}$ & $29^{b}$ & $32^{\mathrm{a}}$ & $20^{\mathrm{a}}$ & $0.011^{\mathrm{b}}$ & $1.06^{\mathrm{b}}$ & $60^{\mathrm{b}}$ \\
\hline K1 & $132^{\mathrm{a}}$ & $73^{\mathrm{a}}$ & $44^{\mathrm{a}}$ & 32 & $62^{\mathrm{a}}$ & $38^{\mathrm{a}}$ & $38^{\mathrm{a}}$ & $23^{\mathrm{a}}$ & $0.032^{\mathrm{a}}$ & $1.31^{\mathrm{a}}$ & $75^{\mathrm{a}}$ \\
\hline So & $115^{\mathrm{b}}$ & $53^{\mathrm{b}}$ & $32^{\mathrm{b}}$ & $23^{\mathrm{b}}$ & $50^{\mathrm{b}}$ & $23^{\mathrm{b}}$ & $39^{\mathrm{a}}$ & $26^{\mathrm{a}}$ & $0.017^{\mathrm{b}}$ & $0.99^{\mathrm{b}}$ & $78^{\mathrm{a}}$ \\
\hline $\mathrm{S} 1$ & $123^{\mathrm{a}}$ & $76^{a}$ & $46^{\mathrm{a}}$ & $34^{\mathrm{a}}$ & $63^{\mathrm{a}}$ & $44^{\mathrm{a}}$ & $31^{\mathrm{b}}$ & $17^{\mathrm{b}}$ & $0.026^{\mathrm{a}}$ & $1.38^{\mathrm{a}}$ & $67^{\mathrm{b}}$ \\
\hline
\end{tabular}

Values within a column with same letter are not significantly different $(p<0.05)$.

\section{Discussion}

\subsection{Yield and fruitphysico-chemical characteristics} Our results showed that the application of ammonium sulphate produced a higher yield, fruit weight and fruit dry matter content than ammonium nitrate or urea. Ammonium sulphate $\left(\mathrm{NH}_{4}\right) \mathrm{SO}_{4}$ in the $\mathrm{N}$ - form (containing $24 \%$ sulphur) decreases the soil $\mathrm{pH}$ and might therefore favour the availability and uptake of elements by plants in slightly alkaline soils (Guelser, 2005). Moreover, ammonium assimilation into plant metabolites requires less energy than nitrate assimila- tion because ammonium does not need to be reduced. Plants may save energy by assimilating reduced nitrogen, and this saved energy may be used to increase the production of secondary metabolites (Elwan and Abd El-Hamed, 2011). In addition, the application of ammonium sulphate and nitrate forms resulted in higher fruit quality characteristics than the application of urea. This difference may have resulted because urea is not suitable for fertilisation under conditions similar to those of the present study. The gaseous loss of ammonia following urea fertiliser application may include up to $75 \%$ of total nitrogen, whereas less $\mathrm{N}$ 
volatilisation occurs from other forms of $\mathrm{N}$ fertiliser. The ammonia volatilisation losses with ammonium sulphate were lower ( $4 \%$ of the $\mathrm{N}$ applied) and produced greater nitrate leaching and greater soil acidification than urea (Cantarella et al., 2003). The validity and uptake efficiency of nitrogen depends on the form applied (Sady et al., 2008). Urea-based fertilisers are particularly susceptible to nitrogen volatilisation losses in warm climates and light-textured soils with $\mathrm{pH}$ greater than 7 (Nielsen, 2006). These growing conditions are similar to those of the Zaghloul palms investigated by the present study. The differences in plant yield responses to the various forms of $\mathrm{N}$ fertiliser are due primarily to differences in the $\mathrm{N}$ losses from the soil rather than to differences in the $\mathrm{N}$ assimilated (Abassi et al., 2005).

Our results showed that the application of $\mathrm{KO}_{2}$ fertilisation significantly increased fruit weight, length, width and colour. Although $\mathrm{K}$ is not a constituent of any organic molecule or plant structure, it is involved in numerous biochemical and physiological processes vital to plant growth, yield, quality and stress (Cakmak, 2005). Adequate $\mathrm{K}$ nutrition has also been associated with increased yields, fruit size, increased soluble solids, improved fruit colour, increased shelf life, and shipping quality of many horticultural crops (Kanai et al., 2007).

The effectiveness of sulphur in increasing fruit yield and quality is clearly documented by reports that plants assimilate inorganic sulphate into cysteine, which is converted into methionine (Nicoforova et al., 2003). This amino acid and others (e.g., tryptophan or phenylalanine) are precursors for the production of glucosinolate, a group of health-promoting compounds (Schonhof et al., 2007). N and S interact to exert a strong effect on various growth parameters, such as biomass and yield (Salvagiotti and Miralles, 2008). Sulphur is an essential constituent of enzymes involved in $\mathrm{N}$ metabolism (Swamy et al., 2005), and its availability could lead to an increase in $\mathrm{N}$ assimilation. Elemental sulphur is strongly involved in improving nutrient assimilation and in stimulating the anti-oxidative defence system of plants through its metabolite glutathione (Gondent and Ullman, 2000).

\subsection{Leaf and fruit mineral content}

Generally, the beneficial effects of N1 on leaf and fruit mineral contents, such as the contents of $\mathrm{P}, \mathrm{Ca}, \mathrm{K}, \mathrm{Fe}$ and $\mathrm{Zn}$, might be attributed to the ability of N1 to reduce the soil $\mathrm{pH}$. Decreases of up to $1.7 \mathrm{pH}$ units can be achieved in the $0-20 \mathrm{~cm}$ depth layer (Cantarella et al., 2003). This acidity increases the availability of nutrients, such as $\mathrm{P}, \mathrm{Mn}, \mathrm{Ca}$, and $\mathrm{SO}_{4}$, in soils (Marschner, 1995). It also enhances the solubility of nutrients and increases the activity of micro-organisms, thereby increasing the plant's ability to absorb and transfer mineral elements (Kandil et al., 2010). The superior effect of ammonium sulphate on leaf $\mathrm{N}$ content may be attributed to lower $\mathrm{N}$ volatilisation.

Fruit $\mathrm{Cd}$ and $\mathrm{Pb}$ content increased when $\mathrm{N}$ was applied in nitrate form. The influences of different nitrogen sources on $\mathrm{Cd}$ accumulation in plants have been reported by others (Mair et al., 2002), who found that the use of calcium nitrate as the $\mathrm{N}$ source resulted in a significantly higher fruit $\mathrm{Cd}$ content compared with ammonium sulphate. In addition, Shahein et al. (2003) found that ammonium nitrate increased fruit Cd compared with urea. Additionally, Alpha et al. (2009) reported that $\mathrm{NH}_{4}^{+}-\mathrm{N}$ treated plants had the highest $\mathrm{N}$ and lowest $\mathrm{Cd}$ concentrations, whereas $\mathrm{NO}_{3}^{-}-\mathrm{N}$ treated plants had the lowest $\mathrm{N}$ and highest Cd uptake.

An increase in the leaf or fruit N, P, K, Fe, Zn and $\mathrm{Mn}$ contents in response to the application of $\mathrm{K}_{2} \mathrm{O}$ fertiliser has been previously noted under experimental conditions similar to those used in this study (Kassem 
et al., 1997). The uptake of nutrients, particularly cations, is significantly influenced by $\mathrm{K}_{2} \mathrm{O}$ fertilisation. $\mathrm{K}$ has thus been shown to affect the absorption, translocation and distribution of other cations (Epstein, 1972). However, the lack of any effect of $\mathrm{K}_{2} \mathrm{O}$ fertilisation on the $\mathrm{Ca}$ and $\mathrm{Mg}$ contents was expected. Cation antagonism between $\mathrm{K}^{+}$and $\mathrm{Mg}^{++}$(Eaton, 1971) and between $\mathrm{K}$ and $\mathrm{Ca}$ (Fageria, 1983) could possibly explain the decrease in leaf $\mathrm{Mg}$ and $\mathrm{Ca}$ content with $\mathrm{K}$ application.

The fruit $\mathrm{Cd}$ and $\mathrm{Pb}$ content increased with $\mathrm{K}$ and $\mathrm{S}$ fertilisation. Many previous studies have confirmed the positive effect of potassium sulphate on $\mathrm{Cd}$ uptake by plants (Zhao et al., 2003). These authors reported that $\mathrm{K}$ fertilisers are always accompanied by anions, such as sulphate, which have been reported to increase $\mathrm{Cd}$ concentrations in plants. In addition, the sulphur anion, whether applied as a sole treatment or accompanied by $\mathrm{K}$, was also found to increase $\mathrm{Cd}$ accumulation in plants (Grant et al., 1999). However, McLaughlin et al. (1998) showed no significant increase in Cd uptake in response to sulphur and suggested that sulphur would not have the same effect as chloride on Cd uptake. A strong relationship between soil salinity (chloride concentration) and $\mathrm{Cd}$ accumulation has been reported (Norvell et al., 2000). Thus, studies of the effects of $\mathrm{K}$ and $\mathrm{S}$ fertilisation and soil conditions on plant $\mathrm{Cd}$ and $\mathrm{Pb}$ accumulation are very important to minimise the concentrations of these heavy metals in agricultural products.

The acidity produced during elemental sulphur oxidation increases the availability of nutrients, such as $\mathrm{P}, \mathrm{Mn}, \mathrm{Ca}$, and $\mathrm{SO}_{4}$, in soils. This effect may enhance the growth performance of plants (Marschner, 1995). The application of elemental of sulphur had positive effects on the concentrations of date palm leaf $\mathrm{Fe}, \mathrm{Mn}, \mathrm{Zn}$, and $\mathrm{Cu}$ (Mohamed et al., 2006). It is probable that these increases resulted from increased availability and uptake through the modification of the soil pH, as reported by Marschner (1995). Sulphur fertilisation significantly influenced the uptake of all elements except phosphorus (Aires et al., 2007).

Recently, the possible human health effects of high nitrate content in vegetables and fruits have been a topic of concern. Approximately 5-10\% of ingested nitrate is converted into the more toxic nitrite through salivary or gastrointestinal reduction (Boink and Speijers, 2001). Compared with ammonium nitrate, fertilisation with ammonium sulphate and urea has been shown to lower the nitrate content in the edible parts of plants (Sady et al., 2008). Similar findings were obtained in the present study. The nitrate content of the fruits was lower with the ammonium sulphate and urea applications than with ammonium nitrate. Nitrate accumulation in plants is very low if nitrogen is applied in the $\left(\mathrm{NH}_{4}\right)_{2} \mathrm{SO}_{4}$ form because this form is slowly nitrified (Goh and Vityakan, 1986). Ammonium sulphate and urea application decreased nitrate accumulation more rapidly than ammonium nitrate (Elwan and Abd El-Hamed, 2011).

\section{Conclusion}

The results of this study indicate that the application of ammonium sulphate as a $\mathrm{N}$ source produced a greater fruit yield and a higher overall product quality of the Zaghloul dates in the experiment. In particular, the use of this $\mathrm{N}$ source produced lower contents of nitrate and heavy metal. Special care must be taken if date palms are fertilised with potassium and sulphur because their application rate, their form and the soil salinity might affect the uptake of heavy metals. The proper use of these fertilisers can produce dates of the highest quality and prevent any risk to human health. In addition, this study found that the sulphur application improved the efficient use of the nitrogen and potassium fertilisers in the calcareous soil used in the experiment. 


\section{Acknowledgments}

It is with sincere respect and gratitude that we express our deep thanks to the Deanship of Scientific Research, King Saud University and the Agriculture Research Center, College of Food and Agricultural Sciences for financial support, sponsorship and encouragement.

\section{References}

Abassi, M. K., Kasmi, M., Hussan, F. 2005. Nitrogen use efficiency and herbage production of an established grass sward in relation to moisture and nitrogen fertilization. J. Plant Nutr. 28: 1693-1708.

Abbas, F., Fares, A. 2008. Best management practices in citrus production. Tree For. Sci. Biotech. 3, $1-11$.

Abbey, L., Jouce, D.C., Aked, J., Smith, B. 2002. Genotype sulfur nutrition and soil type effects on growth and dry matter production of spring onion. J. Hort. Sci. Biotechnol., 77, pp340-345.

Abou Sayed, T.A., Abd El-Bary, E.A., Al-Ashkar, R.A. 1997. Effect of different sources of irrigation water on soil and prickly pear fruit properties. In: Proc. First Sci. Conf. of Agric. Sci., Fac. of Agric., Assiut Univ., Assiut.

Aires, A., Rosa, R., Carvalho, S., Haneklaus,A., Schnug, E. 2007. Influence of nitrogen and sulfur fertilization on the mineral composition of broccoli sprouts, J. Plant Nutr. 30: 1035-1046.

Al-Kharusi, L.M., Elmardi, M.O., Ali, A., Al-Julanda, F., Al-Said, L., Abdelbasit, K., Al-Alpha, J.M., Chen. J, Zhang, G. 2009. Effect of nitrogen fertilizer forms on growth, photosynthesis, and yield of rice under cadmium stress. J. Plant Nutrition, 32 (2): 306-317.

AOAC. 1995. Association of Official Agricultural Chemists, Official Methods of Analysis, $15^{\text {th }}$ ed. A.O.A.C., Washington, DC.
Barbin, P. 2006. Contrôle et Elements De Maitrise De La Contamination Par La Levure Brettanomyces $\mathrm{Au}$ Cours Du Procedéde Vinification En Rouge: 257. Thèse de doctorat de l'institut national polytechnique de toulouse, France.

Boink, A., Speijers, G. 2001. Health effects of nitrates and nitrites. A review, Acta Hort. 563: 29-36.

Cakmak, I. 2005. The role of potassium in alleviating detrimental effects of abiotic stresses in plants. $\mathrm{J}$ Plant Nutr Soil Sci 168:521-530.

Cantarella, H., Mattos, D., Quaggio, J.A. and Rigolin, A.T. 2003. Fruit yield of Valencia sweet orange fertilized with different $\mathrm{N}$ sources and the loss of applied N. Nutrient Cycling in Agroecosystems, 67, (3): 215-223.

Eaton. G.W. 1971. Effects of NPK fertilizers on the growth and composition of vines in a young cranberry bog. J. Amer. Soc. Hortic. Sci. 96: 426-429.

Elwan, M.W.M, Abd El-Hamed, K.E. 2011. Influence of nitrogen form, growing season and sulfur fertilization on yield and the content of nitrate and vitamin C of broccoli. Scientia Horticultureae, 127 (3): 181-187.

Epstein, E. 1972. Mineral nutrition of Plants-Principles and Perspective. John Wiley and Sons. Inc. New York.

Eriksen, J., Thorup-Kristensen, K., Askegard, M. 2004. Plant availability of catch crop sulfur following spring incorporation. J. Plant Nutr. Soil. Sci. 167: 609-615.

Evanhuis, B., De Waard, P.W. 1980. Principles and practices in plant analysis. FAO Soils Bull. 38, 152-163.

Fageria, N. 1983. Ionic interaction in rice plants from dilute solutions. Pl. Soil 70: 309-316.

Fageria, N.K., Baligar, V.C., 2005. Enhancing nitrogen use efficiency in crop plants. Adv. Agron, 88: 97-185. 
FAO. 2010. Food and Agriculture Organization of the United Nations.

Fuleki, T., Francis, F.J. 1968. Quantitative methods for anthocyanins. 1. Extraction and determination of total anthocyanin in cranberries. J. Food Sci. $33,72-77$.

Goh, K.M.,Vityakan, P.1986. Effects of fertilizers on vegetable production.2. Effects of nitrogen fertilizers. N. Z. J. agric. Res., 29: 485-494.

Gondent, L., Ullman, P., 2000. Glutathione metabolism in plants in relation to stress tolerance. Plant Sulfur Research in Europe, Cost Action 829, Instit. Plant Nutri. Soil Science, Federal Agric. Res. Centre, Braunschweig, Germany, pp. 37-38.

Grant, C.A., Baily, L.D. McLaughlin, M. J.1999. Management factors which influence cadmium concentration in crops. In: McLaughlin M. J., B. R, editors. Cadmium in soils and plants. Dordrecht, The Netherlands: Kluwer Acadenic Publishing :151-198.

Guelser, F. 2005. Effects of ammonium sulfate and urea on NO-3 and NO-2 accumulation, nutrient contents and yield criteria in spinach. Sci. Hort., 106: 330-340.

Holzmueller, E.J., Jose, S., Jenkins, M.A. 2007. Influence of calcium, potassium, and magnesium on Cornus florida L. density and resistance to dogwood anthracnose. Plant and Soil., 290: 189-199.

Kanai, S., Ohkura, k., Adu-Gyamfi, J.J, Mohapatra, P.K., Nguyen, N.T, Saneoka, H., Fujita, K. 2007. Depression of sink activity precedes the inhibition of biomass production in tomato plants subjected to $\mathrm{p}$ [potassium deficiency stress. J Experimental Bot 58: 2917-2928.

Kandil, E.A., Fawzi, M.I.F., Shahin. M.F.M. 2010. The Effect of some Slow Release Nitrogen Fertilizers on Growth,Nutrient Status and Fruiting of "Mit Ghamr" Peach Trees. J. Ame. Sci. 6(12): 195-201.
Kassem, H.A.; El-Sabrout M. B. and Attia M.M. 1997. Effect of nitrogen and potassium fertilization on yield, fruit quality and leaf mineral content in some Egyptian soft varieties. Alex. J. Agric. Res., 42:137-157.

Li, H., Gordon, R., Lada, R., Asiedu, S., Goodyear, N. 2007. Development of high plant population seeding technology: Double-row direct seeding for Brassica vegetables. Abstract of Atlantic Agricultural Science and Communication Workshop. Truro, NS: 18.

Mair, N.A., McLaughlin, M.J., Heap, M., Butt, M., Smart, M.K. 2002. Effect of nitrogen source and calcium lime on soil $\mathrm{pH}$ and potato yield, leaf chemical composition and tuber cadmium concentrations. J. Plant Nutr., 25(3):523-544.

Marschner, H. 1995. Mineral nutrition of higher plants. Acad. Press, London: 262-264.

McLaughlin, M. J, Lambrechs, R. M., Smolders, E., Smart, M.K. 1998. Effevts of sulfate on cadmium uptake by Swiss chard: II. Effects due to sulfate addition to soil. Plant Soil, 202: 217-222.

Mohamed. A.A., Soaud, A.A., El-Konaissi, S.M. 2006. Effect of exogenous application of antistresssubstances and elemental sulphur on growth and stress tolerance of tissue culture derived plantlets of date palm (Phoenix dactylifera L.) cv. 'Khalas' during acclimatization. Journal of Applied Horticulture, 8(2): 129-134.

Murphy, J., Riley, J.P. 1962. A modified single solution method for the determination of phosphorus in natural water. Anal. Chin. Acta 27, 31-36.

Nicoforova, V., Freitag, J., Kempa, S., Adamik, M., Hesse, H., Hoefgen, R. 2003. Transcriptome analysis of sulfur depletion in Arabidopsis thaliana: interacting of biosynthetic pathways provides response specificity. Plant J, 33: 633- 650. 
Nielsen, R.L. 2006. N loss mechanisms and nitrogen use efficiency. Purdue nitrogen management workshops, Purdue University.

Nijjar, G.S. 1985. Nutrition of fruit trees. Mrs Usha Raj Kumar, Kalyani, New Delhi, India, pp.306308.

Norvell, W.A., Wu, J., Hopkins, D.G., Welch, R.M. 2000. Association of cadmium in drum wheat grain with soil chloride and chelate-extractable sopil cadmium. Soil Sci. Soc. Am. J., 64:21622168.

Reuther, W. 1948. The mineral composition of date palm foliage. Proc. Amer. Soc Hort. Sci., 51:137 144.

Sady W., Rozek, S. Domagala-Swiatkiewicz, I., Wojciechowska, R., Kolton, A. 2008. Effect of nitrogen fertilization on yield, $\mathrm{NH}_{4}^{+}$and $\mathrm{NO}_{3}^{-}$content of white cabbage. Acta Sci. Pol., Hortorum Cultus, 7:41-51.

Saleh, M. M.S., Abou-Rayya,M. S., Kassim, N.E. 2000. A comparative study on the effect of fast and slow-release nitrogen fertilizers on nutrition. J. Agric. Sci. Mansoura Univ.,25(4): 2189-2196.

Salvagiotti, F., Miralles, D.J. 2008. Radiation interception, biomass production and grain yield as affected by the interaction of nitrogen and sulfur fertilization in wheat. Eur. J. Agron., 28, pp 282290.
Schonhof, I., Blankenburg, D., Mueller, S., Krumbein, A. 2007. Sulfur and nitrogen supply influence growth, product appearance, and glucosinolate concentration of broccoli. J. Plant Nutr. Soil. Sci., 170: 1-8.

Shahein, A.H., Attala, A.M., Kassem H.A., and Aly, H.S.H. 2003. Effect of applying different organic and inorganic nitrogen sources to Zaghloul and Samany date cultivars on: II. Yield, fruit quality and fruit content of some pollutants. Proc. Int Conf. on Date Palm, 16-19 Sept 2003, College of Agric. and Vet. Med., King Saud Univ., Qassem Branch, Kingdom of Saudi Arabia, pp. 195-207.

Singh, J.P. 1988. A rapid method for determination of nitrate in soil and plant extracts, Plant Soil 110: 137-139.

Statsoft, Inc. 2001. Statistica fuer Windows (Software-system fuer Datenanalyse).

Swamy, U., Wang, M., Tripathy, J.N., Kim, S.K., Hirasawa, M., Knaff, D. B., Allen, J.P. 2005. Structure of spinach nitrite reductase: implications for multi-electron reactions by the iron-sulfur: siroheme cofactor. Biochemistry, 44: 16054-16063.

Zhao, Z., Zhuet,Y., Sally, H.L., Smith, E., Smith, F.A. 2003. Effects of forms and rates of potassium fertilizers on cadmium uptake by two cultivars of spring wheat (Triticum aestivum, L.). Environment International, 29: 973-978. 